\title{
WAKAF DAN PEMBANGUNAN EKONOMI
}

\author{
Murtadho Ridwan \\ Sekolah Tinggi Agama Islam Negeri Kudus (STAIN) Kudus \\ e-mail: adle_hr@yahoo.com
}

\begin{abstract}
Waqf is one of Islam's teachings that contain spiritual and material elements. Waqf is defined as something that is given for the usefulness of the people (as a charity) or for purposes related to Islam. This article aims to embrace the concept of waqf from the perspective of history, figh, and also macroeconomic perspective. The results show that waqf is one of Islamic teachings and also pre-Islamic teachings in providing their places of worship. From the figh perspective, figh scholars have explained the concept of waqf in the books of figh based on the al-Quran, the hadith and also their ijtihad. The concept of figh always undergoes development following the development of human reason. This is because the majority of waqf concepts are based on ijtihad which can change time and place. From the macroeconomic perspective, waqf property plays a role in building the necessary facilities of the community such as places of worship, educational institutions and also health centers. These facilities are believed to improve the quality of Human Resources (Sumber Daya Insani).
\end{abstract}

Keywords: Waqf, Economic Development, and Public Facilities 


\section{Pendahuluhan}

Dalam bahasa Melayu kata wakaf diartikan sebagai sesuatu yang diberikan untuk kegunaan orang ramai bagi keperluan yang berkaitan dengan agama Islam (Teuku Iskandar, 2000: 1542). Biasanya harta wakaf berupa tanah yang digunakan untuk membangunkan tempat ibadah (masjid dan musola), lembaga pendidikan dan pusat kesehatan serta keperluan sosial lain.

Wakaf merupakan salah satu ajaran Islam yang mengandung unsur spiritual dan material. Wakaf banyak memiliki manfaat dan faedah terutama dalam hal membantu fakir miskin untuk meningkatkan kesejahteraan mereka. Ini karena harta wakaf dapat digunakan sebagai modal investasi jangka panjang untuk membangun fasilitas umum yang diperlukan masyarakat (Shalih Abdullah Kamil, 1993: 41).

Wakaf memiliki dua unsur utama, pertama unsur spiritual karena wakaf merupakan cabang ibadah yang dapat mendekatkan diri wakif kepada Allah SWT. Kedua unsur material karena wakaf difahami sebagai usaha menjadikan harta dari kepentingan konsumsi menjadi modal investasi yang dapat menghasilkan barang dan jasa untuk kepentingan masa depan.

Dari pemahaman tersebut, wakaf memiliki tiga unsur penting menurut system ekonomi makro Islam, yaitu: Wakaf dapat mengurangi tingkat suku bunga (Rate Of Interest). Wakaf merupakan salah satu mekanisme redistribusi kekayaan, dan mekanisme wakaf mengandung unsur investasi dan tabungan (Saving). Selain itu, harta wakaf dapat membantu aktivitas ekonomi sebuah Negara, baik digunakan sebagai sumber modal pembangunan atau yang lain. Sifat abadi harta wakaf sangat mendukung penyediaan modal tersebut. Harta wakaf dapat digabungkan dengan harta individu dan dijadikan modal bagi sebuah perusahaan. Sebagian dari keuntungannya dapat ditasarufkan berdasarkan peruntukannya. Harta wakaf juga dapat berfungsi sebagai pendapatan. Ini dapat dilihat jika harta 
wakaf dipinjamkan kepada masyarakat melalui system Qard alHasan (pinjaman kebajikan).

Berdasarkan hal di atas, maka artikel ini akan membahas konsep wakaf ditinjau dari fiqh, perspektif sejarah, dan wakaf perspektif ekonomi makro. Selain itu, peran wakaf dalam pembangunan ekonomi umat dan peran wakaf dalam meningkatkan Sumber Daya Insani (SDI) juga akan dijelaskan.

\section{Pembahasan}

\section{Pengartian dan Dasar Wakaf Pengartian wakaf}

Wakaf dari segi bahasa berasal dari kata Arab "Waqf" yang berarti "al-Habs". Kata tersebut merupakan kata yang berbentuk masdar (infinitife noun) yang secara pokok berarti berdiri atau berhenti. Apabila kata tersebut dikaitkan dengan harta, separti tanah, binatang dan sebagainya kata tersebut berarti pembekuan hak milik untuk manfaat tertentu (Ibnu Mandzur, 1990: 359). Dalam bahasa Melayu wakaf diartikan sebagai sesuatu yang diberikan untuk kegunaan orang banyak (sebagai derma) atau untuk keperluan yang berkaitan dengan agama Islam. Wakaf juga memiliki arti tempat berhenti sebentar (Teuku Iskandar, 2000: 1542).

Sebagai satu istilah dalam syariah Islam, wakaf diartikan sebagai pembekuan hak milik atas mata benda (al-Ain) untuk tujuan menyedekahkan kegunaan atau manfaatnya untuk kebajikan atau kepentingan umum (al-Jurjani, 2000: 328). Sedangkan dalam kitab-kitab fiqh, para ulama fiqh berbeda pendapat dalam memberi definisi wakaf. Perbedaan tersebut adalah sebagai berikut:

Hanafiah mengartikan wakaf sebagai pembekuan kondisi riil benda (al-Ain) atas milik wakif dan menyedekahkan atau mewakafkan manfaatnya kepada sesiapa yang diharapkan untuk tujuan kebajikan (Ibnu al-Humam, 1970: 203). Definisi tersebut 


\section{Murtadho Ridwan}

menjelaskan bahwa kedudukan harta wakaf masih tetap tertahan atau terhenti di tangan wakif itu sendiri. Dengan kata lain wakif masih menjadi pemilik harta yang diwakafkan, sedangkan perwakafan hanya terjadi ke atas manfaat harta itu saja bukan termasuk asset hartanya. Ini karena kuasa pemilikan asset harta yang diwakafkan masih dalam milik wakif.

Sedangkan Malikiyah berpendapat bahwa wakaf adalah menjadikan manfaat suatu harta yang dimiliki (walaupun pemilikannya dengan cara sewa) untuk diberikan kepada orang yang berhak dengan satu akad (shighat) dalam jangka waktu tertentu sesuai dengan keinginan wakif (al-Dusuqi, tt: 75). Pengartian wakaf tersebut hanya menentukan pemberian wakaf kepada orang atau tempat yang berhak. Diantara orang yang berhak adalah fakir miskin, anak yatim, orang tua yang sudah renta yang tidak ada seorang pun yang menanggung biaya hidupnya. Sedangkan tempat yang layak menerima wakaf adalah tempat ibadah (masjid atau musola), lembaga pendidikan, pusat kesehatan, pantai asuhan dan tempat-tempat lain yang dibolehkan syara'.

Kelompok Syafi'iyah mengartikan wakaf dengan menahan harta yang bisa memberi manfaat serta kekal bendanya (al-Ain) dengan memutuskan hak pengelolaan yang dimiliki wakif untuk diberikan kepada tempat yang dibolehkan (al-Syarbini, tt: 376). Kelompok ini mensyaratkan harta yang diwakafkan harus harta yang kekal bendanya dengan maksud, harta yang tidak rusak serta dapat diambil manfaat secara berterusan separti tanah, rumah, binatang dan alat perabotan (al-Syairazi, 1976: 575).

Sedangkan Hanabilah mengartikan wakaf dengan menahan asal harta yang berupa tanah dan menyedekahkan manfaat yang dihasilkan (Ibnu Qudamah, 1972: 185). Arti wakaf ini sesuai dengan definisi yang sampaikan Rasulullah SAW yang terdapat dalam hadis Abdullah bin Umar yang menjadi dalil disyariatkannya wakaf Khairi (kebajikan). Arti hadis tersebut adalah: "Telah diriwayatkan bahwa Umar telah memperoleh tanah di Khaibar, lalu dia bertanya kepada Nabi dengan berkata: Wahai Rasulullah, 
saya telah memperoleh tanah di Khaibar yang nilainya tinggi dan tidak pernah saya peroleh yang lebih tinggi nilainya daripada tanah tersebut. Apa yang engkau perintahkan kepadaku? Rasulullah SAW bersabda: Jika kamu mau, tahanlah pokoknya dan sedekahkan hasilnya. Lalu Umar menyedekahkannya, harta tersebut tidak dapat dijual, dihadiahkan, atau diwariskan. Umar menyedekahkan kepada fakir miskin, keluarga, memerdekakan budak, orang yang berperang, orang musafir dan para tamu. Bagaimanapun, hasil tanah tersebut bisa digunakan dengan baik oleh pihak yang mengelolanya, separti memakan atau memberi makan kawan tanpa menjadikannya sebagai sumber harta." (HR. Muslim)

Definisi wakaf menurut hadis tersebut di atas bukan saja menjelaskan tentang konsep wakaf, namun lebih luas dan mempunyai implikasi terhadap harta dan juga distribusi harta wakaf tersebut (Syed Othman, 1987: 23). Berdasarkan maksud wakaf tersebut, jelas menunjukkan bahwa Isam sangat mementingkan pemerataan terhadap umatnya dalam menikmati hasil yang berterusan dengan mendistribusikan sebagian harta yang dimiliki kepada orang lain.

Dari beberapa definisi wakaf tersebut di atas maka ajaran wakaf berimplikasi kepada perluasan hak mengunakan dan mengambil manfaat oleh pemilik asal ke atas harta berkaitan untuk kepentingan pihak yang menerima wakaf. Dengan demikian pemilik asal tidak lagi berhak apa-apa atas kegunaan harta yang diwakafkan. Di samping itu menurut madzhab Syafi'i, praktik wakaf juga melibatkan pembekuan hak milik asal ke atas harta itu sendiri. Wakaf tidak melibatkan perpindahan milik kepada sesiapa tetapi menjadikan harta tersebut dikembalikan kepada pemilik asal yang hakiki yaitu Allah SWT (al-Syairazi, 1876: 389). Dalam bahasa manajemen harta wakaf dikembalikan menjadi milik Negara (Mahmood Zuhdi, 1999: 2)

\section{Dasar hukum wakaf}

Mayoritas ulama menyebutkan bahwa wakaf merupakan ibadah yang disyariatkan. Hal ini disimpulkan dari pengertian- 


\section{Murtadho Ridwan}

pengartian umum dari ayat-ayat al-Quran yang menerangkan tentang sedekah dan juga disimpulkan dari hadis yang secara khusus menceritakan tentang wakaf di masa Rasulullah (Wahbah al-Zuhaili, 1989: 8/157).

Secara umum tidak ada ayat al-Quran yang menerangkan konsep wakaf secara jelas. Oleh karena wakaf termasuk sedekah, maka dasar yang digunakan para ulama dalam menerangkan konsep wakaf ini pada umumnya didasarkan pada ayat-ayat alQuran yang menjelaskan tentang sedekah secara umum. Diantara ayat tersebut adalah ayat 267 surat al-Baqarah yang artinya: "Hai orang-orang yang beriman, nafkahkanlah (di jalan Allah) sebagian dari hasil usahamu yang baik-baik dan sebagian dari apa yang Kami keluarkan dari bumi untuk kamu." (QS. Al-Baqarah: 267)

Ayat lain yang menjadi dalil adalah ayat 92 surat Ali Imran yang artinya: "Kamu sekali-kali tidak sampai kepada kebajikan (yang sempurna) sebelum kamu menafkahkan sebagian harta yang kamu cintai." (QS. Ali Imran: 92)

Ayat lain yang menjelaskan tentang sedekah adalah ayat 261 surat al-Baqarah yang artinya: "Perumpamaan (nafkah yang dikeluarkan oleh) orang-orang yang menafkahkan hartanya di jalan Allah adalah serupa dengan sebulir benih yang menumbuhkan tujuh bulir, pada tiap-tiap bulir seratus biji. Allah melipatgandakan (pahala) bagi siapa yang Dia kehendaki dan Allah maha Luas (karunia-Nya) lagi maha Mengetahui." (QS. Al-Baqarah: 261)

Ayat-ayat tersebut di atas menjelaskan tentang anjuran untuk menyedekahkan harta yang diperoleh untuk mendapatkan pahala. Di samping itu, ayat 261 surat al-Baqarah telah menyebutkan pahala yang akan diperoleh orang yang menyedekahkan hartanya dengan perumpamaan yang ditentukan oleh Allah.

Hadis yang diriwayatkan oleh Anas bin Malik menjelaskan bahwa Abu Thalhah adalah seorang sahabat Ansar yang paling banyak memiliki kebun kurma di Madinah. Di antara kebun 
kurma yang paling disukai adalah kebun kurma di Bairuha' yang letaknya berhadapan dengan masjid. Pada saat firman Allah ayat 92 surat Ali Imran diturunkan kepada Rasulullah SAW, Abu Thalhah berkata kepada Nabi: "Sesungguhnya harta yang paling aku sukai adalah hartaku di Bairuha' dan sesungguhnya hartaku di Bairuha' itulah yang aku wakafkan ke jalan Allah." (al-Asqalani, tt: 387).

Di antara hadis yang menjadi dalil wakaf adalah hadis Abdullah bin Umar yang menceritakan tentang kisah Umar bin Khattab ketika mendapatkan tanah di Khaibar, lalu ia meminta petunjuk Nabi tentang tanah tersebut. Nabi SAW menganjurkan untuk menahan asal tanah tersebut dan mensedekahkan hasilnya. Hadis lain yang menjelaskan tentang wakaf adalah hadis yang diriwayatkan oleh Abu Dawud dari Abu Hurairah. Hadis ini menerangkan bahwa terdapat tiga perkara yang mempunyai pahala tidak terputus diantaranya adalah sedekah jariyah. Para ulama ahli Hadis menafsirkan sedekah jariyah dengan wakaf (al-Syaukani, tt: 24), ini karena kelangsungan pahala wakaf tidak terputus dan karena wakaf merupakan sedekah yang bersifat abadi (perpectual).

Hadis lain yang diriwayatkan oleh Ibnu Majah dari Abu Hurairah juga menyebutkan tentang amal kebajikan yang akan selalu mendapatkan pahala meskipun orang yang melakukan telah meninggal dunia. Arti hadis tersebut adalah: "Sesungguhnya di antara amal kebajikan seorang muslim yang akan mengikutinya setelah dia mati adalah ilmu yang diajarkan dan disebarkan, anak soleh yang dilahirkan, mushaf yang diwariskan, masjid yang dibangun, rumah yang digunakan untuk Ibnu Sabil (beristirahat) yang dibangun, sungai yang dialirkan, sedekah yang dikeluarkan dari hartanya pada saat ia hidup dan ketika ia sehat. Semua itu akan mengikutinya setelah ia meninggal dunia." (HR. Ibnu Majah)

Selain dalil dari al-Quran dan Hadis di atas, para ulama juga telah bersepakat (Ijma') menerima wakaf sebagai satu amal jariyah yang disyariatkan dalam Islam. Tidak ada seorang pun yang menafikan dan menolak ajaran wakaf dalam Islam karena 


\section{Murtadho Ridwan}

wakaf telah menjadi ajaran yang selalu diutamakan oleh para sahabat Nabi, para ahli ibadah yang suka bersedekah serta para ahli ilmu yang suka mendekatkan diri kepada Allah SWT. Hal tersebut separti yang diungkapkan oleh Jabir dalam perkataannya: "Tidak ada seorang pun dari sahabat Nabi yang mampu kecuali mereka memberi wakaf. Ajaran ini telah menjadi kesepakatan (ijma') di antara mereka, maka sesungguhnya orang yang mampu telah melakukannya dan terkenallah ajaran wakaf itu. Oleh karena itu tidak ada seorang pun yang menolaknya sehingga jadilah sebagai kesepakatan (Ijma') di antara mereka" (Ibnu Qudamah, 1972: 187).

\section{Wakaf dalam perspektif sejarah}

Imam Syafi'i berkata: "Setahu saya, orang-orang Jahiliyah tidak menahan (mewakafkan) rumah dan tanah untuk tujuan kebajikan, akan tetapi yang menahan (mewakafkan) untuk tujuan kebajikan adalah orang-orang Islam" (al-Syafi'I, 1993: 4/61)

Perkataan al-Syafi' i tersebut dijadikan dasar oleh sebagian sarjana Muslim setelahnya. Mereka berpendapat bahwa sistem wakaf hanya dikenal dalam ajaran Islam, tetapi dalam sejarah terdapat bukti bahwa umat-umat sebelum Islam telah mengenal transaksi harta benda yang tidak terlepas dari pengartian wakaf dalam islam.ini karena umat-umat terdahulu telah mengenal beribadah kepada Tuhan sesuai dengan cara dan keyakinan mereka. Mereka memerlukan tempat khusus serta biaya tertentu untuk mengurus dan menjaga keberlangsungan tempat-tempat ibadah mereka. usaha-usaha mereka untuk menyediakan tempat ibadah dan mengumpulkan biaya pengelolaan tempat tersebut dapat difahami sebagai konsep wakaf secara sederhana (alKubaisi, 1977: 21).

Di antara contoh yang dapat menjadi bukti berlakunya wakaf sebelum Islam adalah wakaf yang dilakukan oleh nabi Ibrahim dalam membangun Ka'bah yang disebut dalam alQuran sebagai Bait al-Atiq (rumah kuno). Pada awalnya Ka'bah dijadikan sebagai tempat keamanan dan ketenangan untuk 
masyarakat Arab. Kemudian tempat tersebut dijadikan sebagai tempat sembahyang dan meletakkan berhala-berhala mereka untuk mendekatkan diri kepada Tuhan (al-Kubaisi, 1977: 22). Selain itu terdapat masjid al-Aqsha, Masjid al-Haram serta gerejagereja yang dibangun untuk tempat ibadah yang tidak dimiliki oleh seseorang (Abu Zahrah, 1959: 7).

Dalam sejarah Islam, wakaf agama yang pertama dilakukan oleh Rasulullah SAW adalah wakaf yang berkaitan dengan masjid Quba' yang dibangun oleh Rasulullah SAW ketika hijrah ke Madinah (Ali Jumuah, 1993: 19). Lalu diikuti dengan masjid Nabawi di Madinah yang dibangun pada tahun pertama hijrah di atas tanah milik dua anak yatim. Pada awalnya tanah tersebut akan dibeli oleh Nabi, namun mereka berkata kepada Nabi: "Tidak, demi Allah kita tidak akan mengambil harga tanah tersebut, kita hanya mengharapkan pahala dari Allah." Sedangkan wakaf Am pertama yang dilakukan adalah wakaf tujuh kebun atau taman oleh sahabat dari bangsa Yahudi yang bernama Mukhairik yang telah terbunuh di saat perang Uhud (Ali Jumuah, 1993: 92). Setelah itu para sahabat meneruskan praktik wakaf ini, separti Abu Bakar yang telah mewakafkan rumah untuk anakanaknya, Umar bin Khattab yang mewakafkan kebubn Khaibar, Utsman bin Affan yang mewakafkan sumur Rumah dan Ali bin Abu Thalib yang telah mewakafkan tanah Yanbu' miliknya (Ibnu Qudamah, 1972: 186).

Sejarah praktik wakaf tidak berhenti di situ saja, para sahabat Nabi yang lain separti Sa'd bin Abi Waqqas, Amr bin al-'Ash, Hakim bin Huzam dan sahabat-sahabat lain telah melakukan praktik wakaf. Baik berupa wakaf khas yang lebih dikenal dengan wakaf keluarga (Waqf al-Ahli) ataupun wakaf Am atau yang dikenal dengan wakaf kebajikan (Waqf al-Khairi) (Syed Khalid, 2002: 16). Sejarah juga membuktikan bahwa praktik wakaf tidak hanya dilakukan oleh para sahabat dan masyarakat umum tetapi juga dilakukan oleh pihak pemerintah dan keluarga Raja. Permaisuri, isteri dari Khalifah Harun al-Rasyid dilaporkan 


\section{Murtadho Ridwan}

telah mewakafkan segala hartanya untuk menyediakan jalan yang selamat dan mudah untuk tujuan perjalanan haji dari Baghdad ke Makkah (Mohd. Daud Bakar, 1999: 10)

Untuk melihat lebih jelas bagaimana meluasnya praktik wakaf dalam masyarakat Islam, cukup meneliti satu fakta bahwa tiga perempat tanah dinasti Utsmani di Turki adalah tanah wakaf. Selain itu, telah dilaporkan bahwa jumlah tanah pertanian yang diwakafkan adalah separuh dari tanah di Algeria di pertengangahan abad ke sembilan belas dan berjumlah satu partiga dari tanah di Tunisia pada tahun 1883 dan satu perdelapan di Mesir pada tahun 1949 (Murat Cizakca, 1997: 69). Di Yordania, Arab Saudi dan Sri Lanka juga banyak ditemukan praktik wakaf yang dikelola dengan baik sehingga banyak membantu pertumbuhan ekonomi umat dan kesejahteraan masyarakat (Uswatun Hasanah, 2003).

Praktik wakaf ini juga berlaku di Negara-negara Islam yang lain termasuk Indonesia. Menurut data Badan wakaf Indonesia hingga 2016, aset wakaf yang berupa tanah berjumlah 475.768 lokasi dengan luas mencapai 4.359.443.170 $\mathrm{m}^{2}$. Tanah wakaf tersebut sebagian besar baru dimanfaatkan untuk pendirian masjid, panti asuhan, sarana pendidikan dan kuburan dan hanya sebagian kecil yang dikelola secara produktif (BWI, 2017)

\section{Wakaf dalam perspektif ekonomi makro}

Ajaran wakaf memiliki dua unsur utama yaitu unsur spiritual dan material. Wakaf dikatakan memiliki unsur spiritual karena wakaf merupakan cabang ibadah yang dapat mendekatkan diri si wakif kepada Allah SWT. Sedangkan unsur material dapat dilihat dari sudut ekonomi. Dari sudut ekonomi wakaf difahami sebagai usaha menjadikan harta dari kepentingan konsumsi menjadi modal investasi yang dapat menghasilkan barang dan jasa untuk kepentingan masa depan, baik untuk kepentingan kelompok masyarakat atau kepentingan individu (Monzer Kahf, 2000: 66) 
Dari pemahaman di atas, wakaf memiliki tiga unsur penting menurut system ekonomi makro Islam, tiga unsur tersebut adalah:

Pertama, wakaf dapat mengurangi tingkat suku bunga (Rate Of Interest). Ini karena salah satu ciri utama dari system ekonomi Islam adalah larangan Riba dalam aktifitas ekonomi. Sementara bunga merupakan salah satu unsur utama dalam system ekonomi konvensional dan sebagai penentu berlakunya system ekonomi tersebut. Menurut ekonomi Islam, wakaf dapat mengurangi tingkat suku bunga secara nyata. Wakaf dapat memainkan peranan yang sangat penting dalam menyediakan fasilitas public yang diperlukan masyarakat tanpa membebankan biaya kepada pihak pemerintah. Hal ini dapat dilakukan dengan mengumpulkan dana wakaf dari orang-orang kaya dan mengunakan dana tersebut untuk membangun fasilitas umum yang diperlukan masyarakat (Murat Cisakca, 1997: 65).

Pada umumnya fasilitas umum yang disediakan oleh dana wakaf berupa tempat ibadah (masjid dan musola), lembaga pendidikan, pusat kesehatan dan juga kuburan. Sebagai contoh, masjid dapat digunakan masyarakat untuk melaksanakan solat berjamaah dan kegiatan lain sehingga terwujud masyarakat yang harmonis. Pusat kesehatan dapat digunakan untuk menolong orang sakit dan memudahkan masyarakat dalam mendapatkan perawatan kesehatan. Sedangkan lembaga pendidikan dapat digunakan para pelajar untuk mencari ilmu pengetahuan sehingga tingkat pendidikan masyarakat dapat ditingkatkan. Sehingga dengan hal itu semua fungsi wakaf yang amat penting menjadi nyata. Wakaf tidak hanya membantu mengurangi belanja Negara yang menyebabkan tingkat suku bunga naik, namun wakaf dapat juga mencapai tujuan ekonomi modern yang lain, yaitu menjadi salah satu mekanisme redistribusi kekayaan yang lebih baik dalam system ekonomi (Murat Cisakca, 1997: 65).

Kedua, wakaf merupakan salah satu mekanisme redistribusi kekayaan. Dalam sejarah Islam kita mengenal dan 


\section{Murtadho Ridwan}

mengakui adanya kepemilikan individu. Kita dapat mengamati bahwa system wakaf merupakan salah satu yang dihasilkan dari kepemilikan individu yang berfungsi sebagai salah satu mekanisme redistribusi kekayaan (Redistribution of Wealth) dalam ekonomi Islam. System wakaf mampu mengurangi ketidaksamaan distribusi pendapatan dan kemiskinan. Hal ini dapat dilakukan dengan memptivasi umat untuk melakukan sedekah jariyah (wakaf) dengan janji akan mendapatkan pahala yang berterusan sesuai dengan hadis tentang wakaf.

Nilai-nilai ajaran Islam mendorong para pemeluknya untuk mendistribusikan ulang kekayaan mereka kepada kaum fakir miskin dan orang yang kekurangan. Hasil penelitian Birol menunjukkan bahwa Islam adalah jalan hidup yang dapat meningkatkan perilaku rendah hati pada penduduk Utsmaniyah di Turki (Birol Baskan, 2002: 22). Dari sifat rendah hati tersebut mereka terdorong untuk melakukan sedekah jariyah (wakaf) yang dapat membantu Negara dalam menyediakan fasilitas umum yang diperlukan masyarakat.

Meskipun teori ekonomi tentang Redistribution menjelaskan bahwa distribusi ulang kekayaan yang didasarkan atas sifat individu separti rendah hati tidak dapat diandaikan dengan hasil yang optimal, namun hasil penelitian Birol di kejaraan Utsmaniyah menunjukkan bahwa masyarakat di kerajaan itu telah terpenuhi kebutuhan hidupnya dengan sempurna dari system wakaf. Pemerintah kerajaan Utsmaniyah telah mewariskan pusat kesehatan, lembaga pendidikan dan badan-badan kesejahteraan yang seluruhnya dibangun dengan system wakaf (Birol Baskan, 2002: 18). Sehingga tidak berlebihan apabila dikatakan: Sistem wakaf yang sudah ada di kerajaan Utsmaniyah telah menyediakan segala fasilitas umum tanpa membebankan biaya kepada Negara. Dengan demikian kita dapat memandang system wakaf sebagai hasil kerja sama antara pemerintah dan individu untuk meningkatkan investasi. 
Ketiga, Mekanisme wakaf mengandung unsur investasi dan tabungan (Saving). Dari penjelasan system wakaf sebagai mekanisme yang dapat menurunkan tingkat suku bunga dan redistribusi kekayaan, dapat disimpulkan bahwa wakaf dari segi ekonomi merupakan tindakan yang mengabungkan antara investasi dan tabungan. Ini karena wakaf sendiri adalah investasi, karena yang dimaksud investasi adalah menghasilkan keuntungan untuk digabungkan dengan modal usaha dan juga untuk digunakan memenuhi kebutuhan hidup, definisi ini sesuai dengan pengartian wakaf. Barang yang diwakafkan dapat menghasilkan kemanfaatan dan fasilitas umum yang diperlukan masyarakat separti yang telah dijelaskan. Harta wakaf yang terkumpul dapat digunakan sebagai modal investasi masa depan untuk kepentingan generasi akan dating yang tidak mementingkan keuntungan dari pengelolanya sebab tujuan utama wakaf adalah untuk kebajikan dan tolong menolong (ta'awun) (Monzer Kafh, 2000: 70). Untuk itu perlu adanya undang-undang yang mengatur harta wakaf disetiap Negara untuk menjaga harta amanah umat dari kesewenang-wenangan orang yang tidak bertangungjawab (Abu Zahrah, 1959: 32).

Harta wakaf dapat membantu aktivitas ekonomi sebuah Negara, baik digunakan sebagai sumber modal pembangunan atau yang lain. Sifat abadi harta wakaf sangat mendukung penyediaan modal tersebut. Harta wakaf dapat digabungkan dengan harta individu dan dijadikan modal bagi sebuah perusahaan. Sebagian dari keuntungannya dapat ditasarufkan berdasarkan peruntukannya. Selain itu, harta wakaf dapat berfungsi sebagai puncak pendapatan. Ini dapat dilihat jika harta wakaf dipinjamkan kepada masyarakat melalui system Qard alHasan (pinjaman kebajikan). Dengan fasilitas ini, masyarakat islam mampu menjalankan aktivitas ekonomi karena ia hanya melibatkan pengelolaan modal yang sudah ada. Secara tidak langsung wakaf berusaha membasmi kemiskinan yang berlaku di 
masyarakat Islam dan akan meningkatkan kesejahteraan Negara (Abd. Shakur, 1994: 20).

\section{Wakaf dan pengembangan ekonomi umat}

Pembangunan adalah satu proses usaha untuk menyusun sebuah masyarakat kea rah memajukan dan meningkatkan kualiti hidup manusia secara individu dan masyarakat. Tujuan akhir pembangunan menurut Islam adalah untuk memuliakan martabat manusia di dunia dan mencapai kebahagiaan di akhirat. Dalam rangka menyusun ekonomi umat, islam dengan pendekatan terpadu dan pro aktif mensyariatkan ajaran wakaf. Melalui ibadah wakaf, Islam mendidik umatnya bahwa setiap individu yang mampu memiliki tanggungjawab social untuk membangun kesejahteraan umat. Setiap muslim mempunyai peran dalam menjamin kesejahteraan masyarakat secara menyeluruh karena pencapaian kesecahteraan akan mewujudkan suasana ekonomi yang stabil dan akhirnya mampu menghasilkan pembangunan ekonomi secara berkelanjutan (Nik Mustapha, 1999: 4).

Usaha untuk mewujudkan kesejahteraan umat tersebut dipraktikkan dalam pembangunan tanah wakaf yang banyak digunakan untuk membangun fasilitas umum separti tempat ibadah (masjid dan musola), lembaga pendidikan, pusat kesehatan dan keperluan social lain. Fasilitas-fasilitas tersebut dibangun untuk membantu meningkatkan kualitas sumber daya islami dalam masyarakat. Ini karena peningkatan kualitas sumber daya islami dipercaya dapat menjadi modal utama untuk pertumbuhan ekonomi umat.

Islam mengambil pendekatan bahwa pembangunan ekonomi perlu disertai dan disumbang oleh setiap anggota masyarakat. Tidak ada seorang pun yang dikecualikan dari peran ini. Justeru ini adalah peluang untuk berpartisipasi dalam aktivitas ekonomi yang perlu disusun untuk semua anggota masyarakat. Usaha untuk melibatkan semua anggota masyarakat dalam perekonomian tidak hanya terbatas pada sector public dan 
sector perdagangan saja. Peran itu juga bisa diambil oleh individu masyarakat dan juga lembaga tertentu. Melalui lembaga wakaf peran ini turut dapat disumbangkan oleh sector individu dan lembaga (Nik Musthapa, 1999: 5).

Lembaga wakaf dapat membantu Negara dalam mengurangi beban belanja pengelolaan fasilitas umum, meningkatkan permintaan akan barang dan jasa serta dapat membantu menyediakan lowongan pekerjaan. Hal ini dapat dijelaskan sebagai berikut:

Pertama, Wakaf dan bantuaannya pada Negara. Manusia merupakan pelaku pembangunan dalam islam. Pembangunan dalam islam mempunyai tujuan kebahagiaan di dunia dan akhirat atau dengan kata lain untuk mencapai keredhaan Allah (M. Syukri Salleh, tt). Oleh sebab itu, pembangunan yang pertama dalam Islam adalah pembangunan manusia yang berakhlak dan mempunyai keahlian untuk mencapai tujuan pembangunan itu sendiri. Untuk mencapai hal tersebut, Negara memiliki kewajiban untama menyediakan fasilitas umum yang diperlukan masyarakat. Diantara fasilitas umum adalah sarana prasarana pendidikan, kesehatan dan fasilitas umum yang lain.

Dalam sejarah, wakaf khairi (kebajikan) sangat memperhatikan pembangunan manusia dengan mendirikan lembaga pendidikan dan pusat kesehatan. Lembaga pendidikan yang dibangun meliputi sekolah tingkat dasar, menengah dan perguruan tinggi. Usaha ini dapat membantu lembaga pendidikan dalam menentukan kurikulum pendidikan dan membebaskan lembaga tersebut dari campur tangan pemerintah. Ini karena biaya yang digunakan dalam pendidikan dihasilkan dari harta wakaf dabn tidak bergantung pada pemerintah (Salih Abdullah Kamil, 1993: 32).

Wakaf juga mempunyai peran penting dalam meningkatkan kesehatan masyarakat Islam. Baik berupa pengobatan, perawatan ataupun usaha penelitian yang berkaitan dengan kesehatan. Ini dapat dibuktikan dengan banyaknya rumah sakit, klinik, apotek, 


\section{Murtadho Ridwan}

serta laboratorium kesehatan yang dibangun di atas tanah wakaf. Sejarah telah membuktikan akan hal tersebut, telah dilaporkan bahwa di kepulauan Sicilia di bawah pemerintahan Islam telah mempunyai 300 sekolah dasar yang dibangun dengan hasil wakaf. Semua biaya pengelolaan sekolah separti gaji pegawai, guru dan keperluan peralatan sekolah telah dipenuhi dengan dana hasil wakaf. Selain itu wakaf juga digunakan untuk membangun sekolah menengah dan juga universitas di kota-kota besar separti al-Aqsha, Damaskus, Baghdad, Kairo dan yang lain. Dari segi kesehatan, banyak rumah sakit yang dibangun dan dibiayai dengan harta wakaf, diantara contohnya adalah rumah sakit alMarastan di Baghdad, rumah sakit al-Mansuri yang diwakafkan oleh Ibnu Nafis serta terdapat 50 rumah sakit di Qordoba yang dibangun dengan harta wakaf (Shalih Abdullah Kamil, 1993: 46). Oleh sebab itu wakaf dapat membantu Negara dalam meringankan kewajiban yang dibebankan terhadapnya sehingga beban biaya fasilitas umum khususnya pendidikan dan kesehatan dapat dikurangi dengan wakaf.

Kedua, Wakaf dan peningkatan permintaan. Teori ekonomi menyatakan bahwa aktivitas ekonomi akan meningkat dan hasil produksi akan bertambah jika terdapat permintaan riil atas barang dan jasa. Dan juga sebaliknya, artinya permintaan yang kurang akan mengakibatkan kurangnya pendapatan dan juga akan berakibat pada lesunya aktivitas ekonomi sehingga pengangguran meningkat.

Islam telah mengajarkan konsep untuk meningkatkan penawaran dengan menganjurkan sedekah termasuk juga zakat. Ini karena sedekah merupakan di antara konsep Islam dalam mendistribusikan kekayaan sehingga terjadi keadilan dalam masyarakat (Mohd. Daud Bakar, 1999: 5). Melalui zakat dan sedekah yang telah didistribusikan kepada mereka yang berhak maka permintaan barang dan jasa akan meningkat. Ini karena orang yang menerima zakat dan sedekah akan memenuhi 
kebutuhan mereka dengan harta yang diterima (Salih Abdullah Kamil, 1993: 42).

Wakaf sebagai salah satu bentuk sedekah mempunyai peran penting dalam meningkatkan penawaran secara berkelanjutan. Hal ini karena wakaf merupakan jenis sedekah yang pada dasarnya bersifat kekal dan distribusinya hanya pada hasil atau manfaat barangan yang diwakafkan. Wakaf merupakan sedekah yang tidak hanya diperuntukkan dalam satu waktu tertentu saja, namun wakaf merupakan sedekah yang diperuntukkan untuk generasi yang akan dating (Salih Abdullah Kamil, 1993: 42). Hikmat dari sedekah akan kembali kepada orang yang melakukan sesuai dengan firman Allah ayat 272 surah alBaqarah yang artinya: "Dan apa jua harta yang halal yang kamu belanjakan (pada jalan Allah) maka (faedah pahalanya) adalah untuk diri sendiri." (QS. Al-Baqarah: 272)

Ayat ini dapat difahami bahwa orang yang bersedekah akan dapat memperoleh manfaat dan hikmah dari sedekahnya. Karena orang miskin yang menerima sedekah akan mengunakan harta sedekah yang diterima untuk kebutuhan mereka sehingga permintaan atas barang dan jasa meningkat dan pengangguran akan berkurang akibat dari permintaan yang meningkat separti yang berlaku dalam teori ekonomi.

Ketiga, Wakaf dan penyediaan peluang kerja. Harta wakaf dapat digunakan untuk membangun tempat kursus dan pelatihan sehingga kualitas sumber daya insani meningkat dan menghasilkan tenaga kerja yang dapat diterima oleh pasar. Hal ini telah dilakukan Yayasan Iqra' di Sri Langka dan Negeria, yaitu dengan membuat tempat kursus dan pelatihan yang dapat memberi kesempatan pelatihan para pengangguran di Negara tersebut sehingga mereka menjadi tenaga terampil (Salih Abdullah Kamil, 1993: 44). Disamping itu harta wakaf dapat dijadikan modal investasi yang dapat menyediakan peluang pekerjaan. Apalagi dengan adanya wakaf tunai (Cash Waqf) dan saham wakaf yang banyak diberlakukan di beberapa Negara. Hal tersebut dapat 


\section{Murtadho Ridwan}

menambah munculnya perusahaan-perusahaan yang banyak memerlukan tenaga kerja terampil sehingga pengangguran dapat dikurangi dengan lembaga wakaf.

\section{Simpulan}

Wakaf merupakan ajaran islam yang mengandung unsur sprititual dan material. Wakaf dikatakan mengandungi unsur spiritual karena wakaf merupakan ibadah yang dapat mendekatkan diri kepada Allah dan Allah telah menjanjikan balasan pahala bagi oran yang melakukan amalan wakaf tersebut.

Untuk melaksanakan sistem wakaf, para ulama fiqh telah menjelaskan konsep ini dalam buku-buku fiqh yang didasarkan pada al-Quran, hadis dan juga ijtihad mereka. Konsep fiqh selalu mengalami perkembangan mengikut perkembangan akal manusia. hal ini karena mayoritas konsep wakaf didasarkan pada ijtihad yang dapat mengalami perubahan waktu dan tempat.

Dari unsur material, amalan wakaf dapat berimplikasi pada pertumuhan sosioekonomi masyarakat. Harta wakaf banyak digunakan untuk membangun fasilitas yang diperlukan masyarakat separti tempat ibadah, lembaga pendidikan dan juga pusat kesehatan. Fasilitas-fasilitas tersebut dipercaya dapat meningkatkan kualitas Sumber Daya Insani (SDI) sehingga dapat membantu setiap individu dalam memerangi kemiskinan yang ada pada diri mereka sendiri.

\section{Daftar Pustaka}

Abnu al-Humam, Syarh Fath al-Qadir, Mathba'ah Mushtafa alHalabi, Kairo, 1970.

Abu Zahrah, Muhadharat fi al-Waqf, Matba'ah Ahmad Ali Mukhaimir, kairo, 1959.

Al-Dusuqi, Hasyiyah al-Dusuqi ala Syarh al-Kabir, Dar Ihya al-Kutub al-Arabiyah, $\mathrm{tt}$. 
Al-Kubaisi, Ahkam al-Waqf fi al-Syariah al-Islamiyah, Matbaah alIrsyad, Baghdad, 1977.

Al-Nawawi, Shahih Muslim bi Syarh al-Imam Muhyiddin al-Nawawi, Dar al-Ma' rifah, Bairut, 1994.

Al-Syafi'i, Kitab al-Umm, Dar al-kutub al-Ilmiyah, Beirut, 1993.

Al-Syairazi, al-Muhadzdzab fi Figh al-Imam al-Syafi'e, Mathba'ah Mushtafa al-Halabi, Kairo, 1976.

Birol Baskan, Waqf System as a Redistribution Mechanism in Ottoman Empire, (Makalah Seminar pada Department of political Science Northwestern University, April 2002).

Ibnu Madzur, Lisan al-Arab, Dar al-Kutub al-Ilmiyah, Beirut, 1990.

Mahmood Zuhdi, Kefahaman Konsep dan Amalan Wakaf di Malaysia Hari ini, (Makalah Seminar Konsep dan Pelaksanaan Wakaf di Malaysia, maret 1999)

Mohd. Daud Bakar, Amalan Institusi Wakaf di Beberapa Negara Islam, (Makalah Seminar Konsep dan Pelaksanaan Wakaf di Malaysia, Maret 1999)

Muhammad Ali Jumu'ah, al-Waqf wa Itharuhu al-Tanmawi, dalam Nahwa Daur Tanmawi li al-Waqf, Wizarah al-Auqaf wa Syu'un al-Islamiyah, Kuwait, 1993.

Murat Cizacka, Toward Comparative Economic History of the Waqf System, Journal al-Sajarah, Vol. 2, No. 2, 1997.

Nik Mustapha, Sumbangan Institusi Wakaf Kepada Pembangunan Ekonomi, (Makalah Seminar Konsep dan Pelaksanaan Wakaf di Malaysia, Maret 1999)

Salih Abdullah Kamil, Daur al-Waqf fi al-Numuwwi al-Iqtishadi, dalam Nahwa Daur Tanmawi li al-Waqfi, Wizarah al-Awqaf wa al-Syu'un al-Islamiyah, Kuwait, 1993.

Syed Othman al-Habsi, Baitul Mal dan Institusi Wakaf, (Makalah Seminar Pembangunan Wakaf dan Baitulmal Negeri Johor, Oktober 1987). 
Teuku Iskamdar, Kamus Dewan, Edisi 3, Dewan Bahasa dan Pustaka, Kuala Lumpur, 2000.

Uswatun Hasanah, Perwakafan di Yordan, Arab Saudi dan Sri Lanka, www. Modalonline.com

Wahbah al-Zuhaili, al-Figh al-Islami wa Adillatuh, cetakan ke-3, Dar al-Fikr, Damaskus, 1989. 